\title{
Dampak Cadmium dalam Ikan terhadap Kesehatan Masyarakat
}

\author{
Agus Purnomo* Rachmadi Purwana**
}

\begin{abstract}
Abstrak
Kandungan Chemicals Oxygen Demand (COD) dan logam Cadmium pada air laut di Indonesia, dalam kisaran 123-398 ppm dan 0,024-0,044 ppm berada di luar batas yang diizinkan (COD $\leq 40$ ppm dan $\mathrm{Cd} \leq 0,01 \mathrm{ppm}$ ). Masyarakat Teluk Lampung setiap hari terpajan dengan ikan Kurisi (Nomipterus hexodon), ikan Kembung (Rastrelliger neglectus), dan ikan Tongkol (Auxis thazard) dengan kadar rata-rata kandungan cadmium 0,146; 0,144; dan 0,137 mg/kg. Penelitian ini bertujuan melakukan analisis risiko dampak pencemaran cadmium pada ikan terhadap kesehatan masyarakat Pulau Pasaran yang berada tepat di hadapan Kota Bandar Lampung di Teluk Lampung. Disain studi yang digunakan adalah disain cross sectional dengan jumlah sampel 284 orang. Hasil penelitian menemukan besar risiko gangguan kesehatan bagi masyarakat pulau Pasaran di Kota Karang-Bandar Lampung yang mengkonsumsi ikan tiga kali sehari adalah 0,574. Disamping itu, secara statistik terdapat hubungan yang signifikan antara besar risiko itu dengan faktor-faktor konsentrasi cadmium dalam ikan, laju asupan ikan, durasi pajanan, dan berat badan responden. Faktor yang berhubungan paling erat adalah konsentrasi cadmium dalam ikan dan durasi pajanan. Masyarakat pulau Pasaran kota Karang-Bandar Lampung telah berisiko mengalami gangguan kesehatan akibat keracunan cadmium kronis yang dapat menyebabkan kerusakan sistem urinaria, respiasi, sirkulasi darah, jantung, kelenjar reproduksi, sistem penciuman dan kerapuhan tulang
\end{abstract}

Kata kunci : Analisis risiko, cadmium, studi kasus, kesehatan masyarakat.

Abstract

This is a risk analysis research of the health impact of cadmium contamination in fish among the community in Pasaran Island. The Pasaran Island lies right across the Bandar Lampung City in the Lampung Bay. On average, the community in the island consumed fish 3 times a day. Study in 2004 reported three types of fishes that were regularly consumed and caught by the community around the Lampung Bay were contaminated by cadmium. Those contaminated fishes were the Kurisi fish (Nomipterus hexodon), Kembung fish (Rastrelliger neglectus), and Tongkol fish(Auxis thazard). In their daily life the community in the Pasaran Island were posed to the risk of exposure to cadmium from the fish (risk agent). This cross-sectional study on 284 samples of the population verifies that the health risk for the community at the Pasaran Island in the Karang-Bandar Lampung City is 0.574 . Besides, statistical analysis showed that the risk is significantly related to factors such as concentration of cadmium in fish, rate of fish consumption, duration of exposure, and respondents body weight. Key words : Risk analysis, cadmium, case study, public health. 
Pembangunan dan pertumbuhan Indonesia pada masa mendatang akan sangat bergantung pada kelestarian sumber daya alam dan perluasan industri. Namun, perluasan industri yang disertai pencemaran merupakan ancaman bagi penduduk perkotaan yang terus meningkat. Pada masa mendatang, hal tersebut akan berpengaruh terhadap prospek kualitas kehidupan yang lebih baik. Reformasi pembangunan industri di Indonesia yang telah membawa banyak perubahan mendominasi pembangunan di daerah dengan kegiatan sektor industri. Peningkatan kegiatan industri dan peningkatan jumlah penduduk di kota besar, umumnya berdampak negatif terhadap lingkungan sekitar sebagai akibat limbah yang dihasilkan dari aktivitas industri dan masyarakat. Buangan industri tersebut antara lain mengandung unsur atau senyawa logam berat yang merupakan toksikan berdaya racun tinggi, karena bersifat toksik terhadap tumbuhan, hewan dan manusia. Pencemaran logam cadmium $(\mathrm{Cd})$ di sekitar sungai Jinzu kota Toyama bagian Barat Jepang menyebabkan kejadian penyakit itai-itai yang ditandai oleh perlunakan tulang (osteomalacia), perapuhan tulang (osteoporosis) yang disertai dengan kerusakan ginjal. ${ }^{1}$

Keracunan akibat logam cadmium yang bersifat kronis terjadi dalam periode waktu yang sangat panjang. Logam cadmium masuk ke dalam tubuh dalam jumlah kecil, tetapi dengan proses pemajanan terus-menerus dan lama akan terakumulasi di dalam tubuh sampai mencapai kadar tertentu yang dapat menimbulkan gangguan kesehatan. Keracunan kronis cadmium menyebabkan kerusakan antara lain pada sistem urinaria (ginjal), respirasi (pernafasan/paru-paru), sirkulasi darah dan jantung serta dapat merusak kelenjar reproduksi, sistem penciuman, dan kerapuhan tulang. ${ }^{2}$

Secara umum, cadmium di udara disyaratkan tidak mencapai kadar $0,5 \mu \mathrm{g} / \mathrm{m}^{3}$, dengan asupan melalui inhalasi 7,5 $\mu \mathrm{g}$ dan yang diabsorbsi sekitar $2 \mu \mathrm{g}$. Asupan cadmium melalui makanan dan air bervariasi sesuai dengan kontaminasi pada beberapa jenis makanan atau suplai air bersih. Asupan harian cadmium yang berada pada kisaran 150-200 $\mu \mathrm{g}$ dilaporkan mencemari sebagian besar jenis makanan dan terserap rata-rata $5 \%$, sehingga asupan harian cadmium dari makanan berkisar antara $8-10 \mu \mathrm{g}$. Total asupan harian logam cadmium berasal dari kontaminasi makanan, air dan udara tidak boleh lebih dari $20 \mu \mathrm{g} .^{2}$

Penelitian Pusat Sumber Daya Wilayah Pesisir yang bekerjasama dengan Coastal Resources Center-University of Rhode Island, USA dan Pusat Kajian Sumber Daya Pesisir dan Lautan (PKSPL) Institut Pertanian Bogor (IPB) menemukan kandungan Chemicals Oxygen Demand (COD) dan logam cadmium (Cd) pada air laut telah berada di luar batas yang diizinkan untuk kegiatan pariwisata dan rekreasi serta budidaya perikanan dan bio- ta laut. Kandungan COD berkisar antara $123-398$ ppm dan Cd berkisar antara 0,024 - 0,044 ppm (baku mutu $\mathrm{COD} \leq 40 \mathrm{ppm}$ dan baku mutu $\mathrm{Cd} \leq 0,01 \mathrm{ppm}) .{ }^{3}$ Kadar rata-rata kandungan logam cadmium pada daging tiga jenis ikan yang banyak dikonsumsi dan ditangkap oleh masyarakat di sekitar Teluk Lampung meliputi ikan Kurisi (Nomipterus hexodon) $(0,146 \mathrm{mg} / \mathrm{kg})$, ikan Kembung (Rastrelliger neglectus) $(0,144 \mathrm{mg} / \mathrm{kg})$ dan ikan Tongkol (Auxis thazard) $(0,137 \mathrm{mg} / \mathrm{kg}){ }^{4}$

\section{Metode}

Penelitian yang menggunakan disain studi cross sectional ini mencakup empat langkah kegiatan analisis. Pertama, Identifikasi Bahaya (Hazard Identification) yang dilakukan dengan analisis konsentrasi logam cadmium dalam ikan di laboratorium. Kedua, Analisis Dosis-Respon berdasarkan referensi Integrated Risk Information System (IRIS). ${ }^{5}$ Nilai RfD (Reference Dose) logam cadmium yang melalui makanan adalah $0,001 \mathrm{mg} / \mathrm{kg} / \mathrm{hari}$. Ketiga, Analisis Pajanan (Exposure Assessment) yang dilakukan dengan mengukur besar pajanan dengan memperhitungkan konsentrasi cadmium dalam ikan, laju asupan, frekuensi pajanan, durasi pajanan, berat badan konsumen, dan periode waktu rata-rata. Keempat, Karakterisasi Risiko (Risk Characterization) didapat melalui estimasi risiko dengan kuantifikasi probabilitas yang merupakan rasio antara asupan dengan dosis acuan $(R f D)$.

Sampel daging ikan basah digerus, ditimbang dengan berat \pm 100 gram dan dikeringkan secara bertahap $( \pm$ $\left.150^{\circ} \mathrm{C}\right)$. Sampel yang telah kering dimasukkan ke dalam cawan porselin dan selanjutnya dimasukkan ke dalam tanur dan diabukan pada suhu $3000^{\circ} \mathrm{C}$. Sampel yang telah menjadi abu dilarutkan dengan $\mathrm{HNO}_{3}$ pekat dan dipanaskan hingga hampir mengering. Selanjutnya, ditambahkan $\mathrm{HNO}_{3}$ dengan konsentrasi $1 \%$, disaring dan selanjutnya filtrat diambil sampai mencapai volume $10-25$ ml. Selanjutnya, sampel siap di uji dengan Spektrofotometer Serapan Atom. Pengolahan data menggunakan metode analisis risiko dengan menghitung asupan untuk mengetahui besar risiko konsumen. Perhitungan asupan didapat berdasarkan data konsentrasi risk agent (cadmium; $\mathrm{mg} / \mathrm{kg}$ ), laju (rate) asupan, frekuensi pajanan tahunan (hari/tahun), durasi pajanan (real time) dalam tahun, berat badan konsumen $(\mathrm{kg})$, periode waktu ratarata (30 tahun x 365 hari/tahun untuk nonkarsinogen).

Data tentang asupan (konsentrasi logam cadmium dalam ikan diperoleh dengan menggunakan persamaan 1. Data yang telah diperoleh melalui pengukuran asupan dan studi pustaka cadmium (RfD: 0,001 $\mathrm{mg} / \mathrm{kg}$ hari) digunakan dalam persamaan pendekatan bilangan risiko (risk quotient, RQ). Risk Quotient (RQ) pajanan cadmium dalam ikan untuk menentukan kemungkinan terjadi resiko kesehatan konsumen, dengan rumus sebagai 


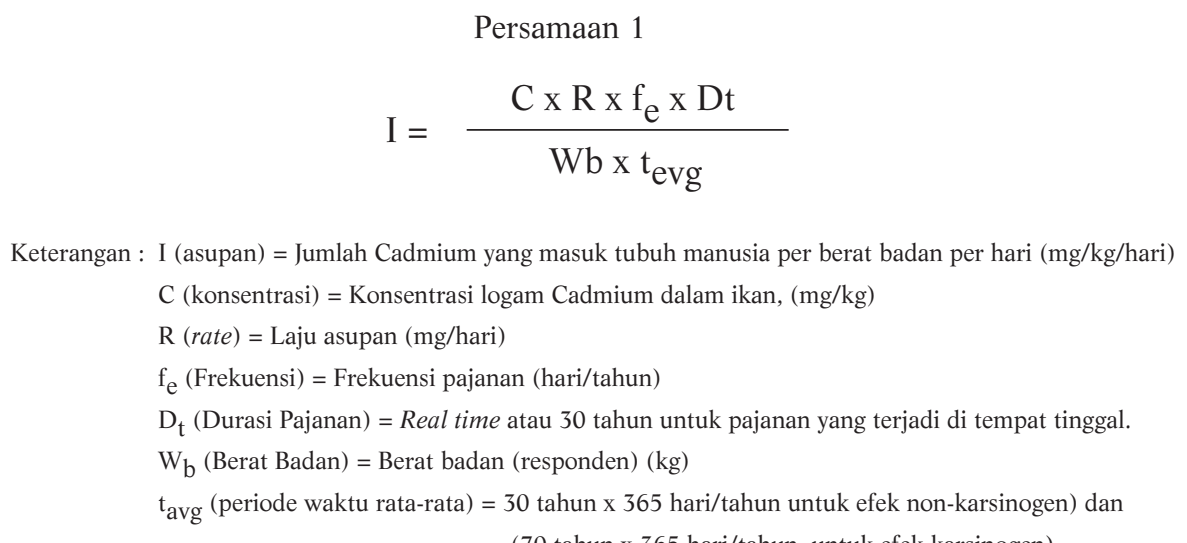

(70 tahun x 365 hari/tahun untuk efek karsinogen)

berikut:

$$
\text { Risk Quotients }(R Q)=\frac{\text { Intake }(\mathrm{mg} / \mathrm{kg} / \mathrm{hari})}{(R f D=0,001 \mathrm{mg} / \mathrm{kg} / \mathrm{hari})}
$$

Hasil perhitungan risk quotients dapat menunjukkan tingkat risiko kesehatan konsumen yang terjadi akibat mengkonsumsi ikan mengandung cadmium. $\mathrm{RQ}<1$ menunjukkan pajanan berada di bawah batas normal. Penduduk yang mengkonsumsi ikan tersebut aman dari risiko kesehatan akibat cadmium sepanjang hidupnya. Nilai RQ $>1$ menunjukkan pajanan berada di atas batas normal, sehingga penduduk pengonsumsi ikan berisiko kesehatan akibat cadmium seumur hidup.

Analisa data mencakup analisa univariat untuk memperoleh gambaran pada masing-masing variabel. Data disajikan dalam bentuk tabel frekuensi maupun diagram-diagram frekuensi, analisa bivariat untuk mengetahui hubungan antara 2 variabel, yaitu antara masing-masing variabel independen (konsentrasi cadmium dalam ikan, laju asupan, durasi pajanan dan berat badan konsumen) dengan variabel besar risiko sebagai variabel dependen. Uji statistik yang dipakai adalah uji regresi linier sederhana untuk data yang variabel dependennya numerik dan uji Chi Square untuk data dengan variabel kategorik dikotom dengan batas Confidence Interval 95\%. Analisis multivariat dilakukan untuk melihat hubungan antara beberapa variabel independen dengan variabel dependen dan untuk mendapatkan suatu model akhir dari analisis untuk memprediksi besarnya risiko gangguan kesehatan akibat logam cadmium berdasarkan variabel konsentrasi cadmium dalam ikan, laju asupan, durasi pajanan, dan berat badan yang menggunakan uji regresi linier ganda.

\section{Hasil}

Pulau Pasaran merupakan daerah penghasil utama ikan olahan (teri asin) di Bandar Lampung, sehingga ikan merupakan lauk utama yang selalu dikonsumsi setiap hari. Sebagian besar masyarakat Pulau Pasaran merupakan pengolah ikan, nelayan dan buruh. Berdasarkan wawancara dengan semua responden diketahui bahwa setiap hari mereka mengkonsumsi ikan laut segar atau ikan asin. Ikan segar umumnya dikonsumsi oleh kelompok profesi nelayan dan pengolah ikan, sedangkan para buruh umumnya mengkonsumsi ikan asin, karena mudah didapat dan tidak perlu membeli. Masyarakat Pulau Pasaran yang mengkonsumsi ikan teri asin $(47,08 \%)$ ikan kembung basah $(16,15 \%)$, ikan teri basah $(26,8 \%)$ dan ikan tanjan asin $(9,97 \%)$.

Distribusi rata-rata dan frekuensi konsentrasi cadmium dalam ikan yang dikonsumsi masyarakat Pulau Pasaran rata-rata adalah $0,212 \mathrm{ppm}$ dengan estimasi selang $95 \%(0,134-0,290 \mathrm{ppm})$. Nilai skewness berada diantara nilai \pm 2 dan mendekati angka nol $(0,376)$, sehingga dapat dinyatakan bahwa konsentrasi cadmium dalam ikan berdistribusi normal. Di samping itu, lebih dari $50 \%$ responden telah mengkonsumsi ikan yang mengandung cadmium dengan konsentrasi lebih dari 0,2 ppm. Padahal, batas konsentrasi cadmium dalam ikan yang direkomendasikan adalah $0,2 \mathrm{mg} / \mathrm{kg}$ atau $0,2 \mathrm{ppm}$. Rata-rata laju asupan per hari konsumsi ikan masyarakat Pulau Pasaran Kota Karang-Bandar Lampung adalah 233,56 gr/hari (95\% CI: 223,74-243,38 g/hari); data laju asupan berdistribusi normal (skewness $=0,579$ ). Sekitar 56,3\% masyarakat tersebut mengkonsumsi ikan lebih dari 233,6 gram/hari. Dari berbagai jenis ikan yang dikonsumsi masyarakat, kadar cadmium tertinggi terdapat pada ikan teri asin yaitu $0,407 \mathrm{ppm}$.

Durasi pajanan juga terdistribusi normal dengan ratarata durasi pajanan adalah 21 tahun dan sekitar 35,2\% masyarakat telah terpajan cadmium melalui ikan lebih dari 25 tahun. Status gizi responden tercermin dari berat badan, sekitar $32 \%$ responden mempunyai berat badan kurang dari $50 \mathrm{~kg}$ dengan rata-rata berat badan 
Gambar 1. Kurva Regresi Linier Hubungan Konsentrasi (C) Dengan Besar Risiko

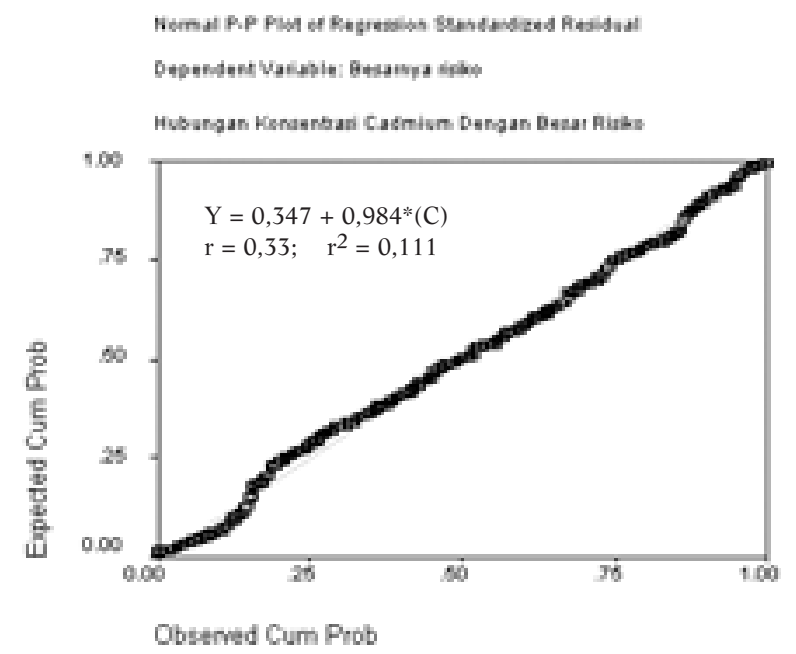

$(56,65 \mathrm{~kg})$ dan estimasi selang 95\% (55,41 - 57,88 $\mathrm{kg})$. Data berat badan tersebut berdistribusi normal dengan nilai skewness $=0,546$ dan sekitar 54,2\% masyarakat Pulau Pasaran mempunyai berat badan kurang dari $56,7 \mathrm{~kg}$.

Sekitar 9,5\% (27) responden yang tinggal di Pulau Pasaran berisiko mengalami gangguan kesehatan akibat mengkonsumsi ikan yang mengandung logam cadmium, sisanya sekitar 90,5\% (257 orang) masih dalam batas tidak berisiko $(\mathrm{R} \leq 1)$. Dari hasil uji univariat didapat kelima variabel independen numerik memenuhi asumsi distribusi normal, yang meliputi variabel konsentrasi cadmium dalam ikan, laju asupan, durasi pajanan, berat badan dan besar risiko gangguan kesehatan. Dengan demikian, analisis lebih lanjut dapat dilakukan dengan analisis regresi linier sederhana.

Konsentrasi cadmium dalam ikan berisiko gangguan kesehatan yang lemah $(r=0,333)$ dan berpola positif. Hal tersebut berarti bahwa semakin tinggi konsentrasi cadmium dalam ikan maka semakin tinggi risiko gangguan kesehatan. Persamaan garis regresi yang diperoleh tampaknya kurang baik untuk menjelaskan variasi besar risiko, karena hanya mampu menerangkan $11,1 \%$ variasi besarnya risiko. Hasil uji statistik didapat nilai $p$-value $=0,000$ yang berarti ada hubungan linier signifikan antara konsentrasi cadmium dalam ikan dengan risiko (Gambar 1).

Laju asupan harian konsumsi ikan yang terbesar ditemukan pada keluarga nelayan yang rata-rata mengkonsumsi ikan basah 400 gram/hari untuk pria dan 300 gram/hari untuk wanita. Pola konsumsi pria per hari rata-rata 4 kali makan dalam sehari, baik saat berada di rumah maupun di laut dengan rata-rata sekali asupan 100 gr. Uji statistik menunjukkan bahwa terdapat
Gambar 2. Kurva Regresi Linier Hubungan Laju Asupan (R) Dengan Besar Risiko

Normal P.P Plot of Regression Standardized Resildual

Desendert Variskle: Bessurtys risko

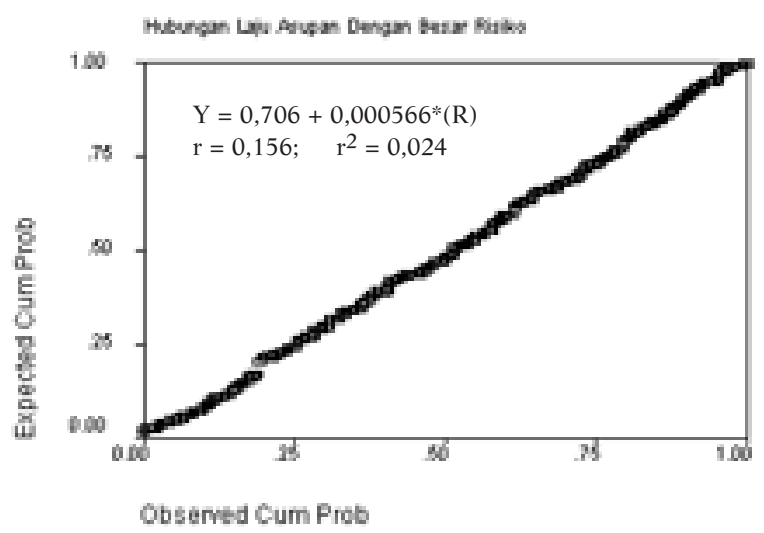

hubungan yang signifikan antara laju asupan dengan besar risiko. Hubungan laju asupan dengan besar risiko gangguan kesehatan memperlihatkan pola yang positif lemah $(r=0,156)$. Persamaan garis regresi yang diperoleh juga kurang baik untuk menjelaskan variasi besarnya risiko, karena hanya mampu menerangkan $2,4 \%$ variasi besarnya risiko (Gambar 2).

Hasil uji statistik menunjukkan hubungan yang sangat bermakna antara durasi pajanan dengan besar risiko gangguan kesehatan (Gambar 3). Hubungan yang kuat (r $=0,725$ ) dan dengan pola positif ini berarti semakin lama durasi pajanan cadmium semakin tinggi risiko gangguan kesehatan. Di samping itu, persamaan garis regresi mampu menerangkan $52,5 \%$ variasi besarnya risiko. Hubungan antara berat badan dengan besar risiko gangguan kesehatan memperlihatkan pola yang negatif, semakin berat badan responden maka semakin kecil risiko gangguan kesehatan. Hubungan tersebut lemah $(r=0,127)$, meskipun dalam uji statistik didapatkan nilai $\mathrm{p}=0,032(<$ 0,05 ) yang menunjukkan hubungan yang bermakna. Persamaan garis regresi yang diperoleh juga kurang baik untuk menjelaskan variasi risiko, karena hanya mampu menerangkan 1,6\% variasi besar risiko (Gambar 4).

Analisis chi square digunakan untuk menilai perbedaan antara kelompok berisiko dan kelompok tidak berisiko akibat pajanan logam cadmium di dalam ikan. Setiap variabel merupakan data numerik dikategorikan dalam 2 kelompok. Penentuan cut of point dari masingmasing variabel, untuk variabel laju asupan dan berat badan menggunakan nilai mean sebagai cut of point karena data kedua variabel tersebut terdistribusi normal, titik potong masing-masing variabel meliputi laju asupan $(233,6 \mathrm{~g} / \mathrm{hari})$ dan berat badan $(56,7 \mathrm{~kg})$. 
Gambar 3. Kurva Regresi Linier Hubungan Durasi Pajanan Dengan Besar Risiko

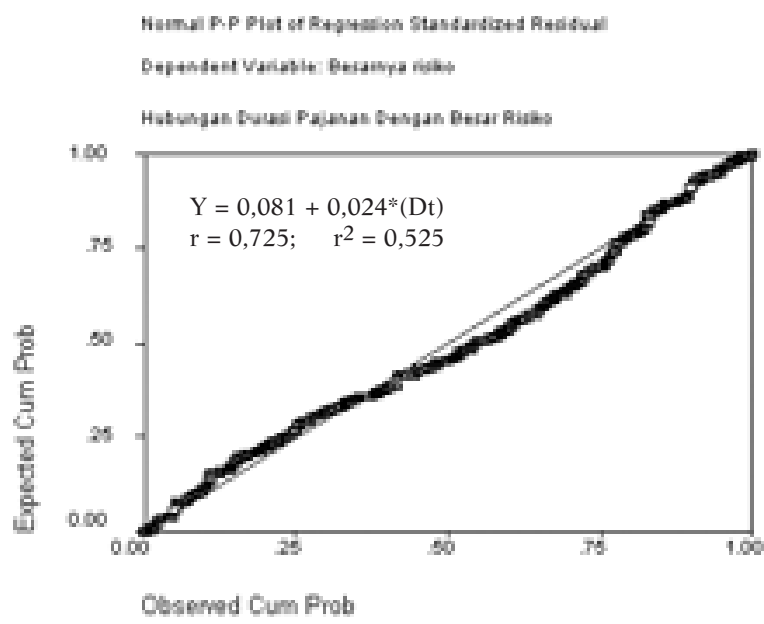

Gambar 4. Kurva Regresi Linier Hubungan Berat Badan Dengan Besar Risiko

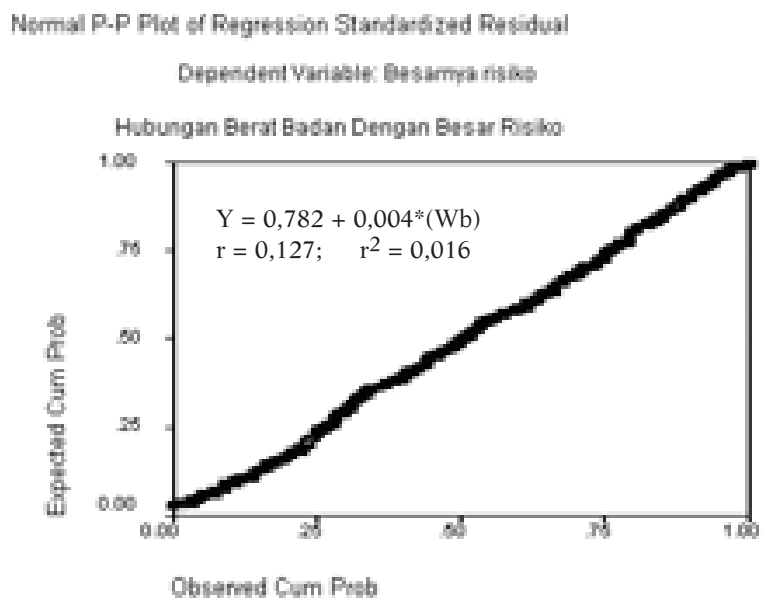

Persamaan 2.

Besar Risiko $=-0,212-0,492 * \mathbf{C}-0,00084 * \mathbf{R}-0,0012 * \mathbf{D t}+0,0139 * \mathbf{W b}+0,0128(\mathbf{C} * \mathbf{R})+0,1250(\mathbf{C} * \mathbf{D t})$ - 0,0404 (C:Wb) + 0,000095 (R*Dt) - 0,000025 (R*Wb) - 0,00039 (Dt*Wb)

Konsentrasi cadmium dalam ikan $(0,2 \mathrm{ppm})$ dan durasi pajanan ( 25 tahun) ditentukan berdasarkan rujukan hasil penelitian.

Penelitian ini menemukan orang yang mengkonsumsi ikan dengan konsentrasi cadmium $>0,2 \mathrm{ppm}$, berisiko gangguan kesehatan 7,23 kali lebih besar pada orang yang mengkonsumsi ikan dengan konsentrasi cadmium $\leq 0,2$ ppm dengan nilai $\mathrm{p}=0,000(<0,05)$. Selanjutnya, orang yang mengkonsumsi ikan dengan laju asupan $\geq 233,6$ $\mathrm{g} /$ hari berisiko sebesar 7,12 kali lebih besar daripada yang dengan laju asupan $<233,6$ gr/hari dengan nilai $p<0,05$. Durasi pemajanan konsumsi ikan $>25$ tahun berisiko 7,89 kali lebih besar daripada orang yang dengan durasi $\leq 25$ tahun dan ini secara statistik bermakna. Berat badan < 56,7 kg berisiko 3,26 kali lebih besar daripada yang berat badan $\geq 56,7 \mathrm{~kg}$ dan secara statistik bermakna ( $p$-value $=0,017)($ Lihat Tabel 1$)$.

Hasil analisis regresi linier ganda didapatkan nilai koefisien determinasi $\mathrm{R}^{2}=0,882$, artinya model regresi linier yang diperoleh ini dapat menjelaskan 88,2\% variasi variabel dependen Besar Risiko (Lihat Tabel 2).

Dalam penelitian ini, semua variabel yang masuk dalam model secara substansi mempunyai kemungkinan berinteraksi. Berdasarkan hasil seleksi pada tabel 2, ternyata semua variabel interaksi mempunyai nilai signifikan $\leq 0,05$ sehingga semua interaksi masuk dalam model akhir, tetapi pada variabel konsentrasi (C) dan durasi pajanan (Dt) masing-masing mempunyai $p$-value $>0,05$. Variabel konsentrasi merupakan variabel utama, sehingga tidak dapat dikeluarkan dari model. Jadi hasil pada ta- bel 2, merupakan model akhir dari proses analisis multivariat dengan regresi linier ganda (Lihat Tabel 2).

Model akhir regresi linier ganda didapatkan nilai $\mathrm{R}^{2}$ $=0,985$, artinya persamaan garis regresi linier yang diperoleh ini dapat menjelaskan $98,5 \%$ variasi besarnya risiko masyarakat untuk mengalami gangguan kesehatan akibat logam cadmium dan hasil uji reliabilitas model diketahui nilai $\mathrm{R}^{2}$ pada sampel pertama sebesar 0,906 dan $\mathrm{R}^{2}$ pada sampel kedua sebesar 0,867 . Selisih nilai split sampel sebesar 0,039 yang berarti tidak ada perbedaan nilai $\mathrm{R}^{2}$ yang besar diantara kedua bagian sampel tersebut sehingga model dapat dikatakan reliable.

Setelah model memenuhi persyaratan asumsi linier dan reliable, maka dapat dinyatakan bahwa model yang didapat pada tabel 2 sudah tepat untuk memprediksi besar risiko pada persamaan 2 .

Berdasarkan persamaan diatas, maka dapat dijelaskan bahwa variabel konsentrasi cadmium dalam ikan (C), laju asupan (R) dan durasi pajanan (Dt) searah dengan variabel dependen (besarnya risiko). Hal tersebut berarti bahwa semakin besar nilai $\mathrm{C}$ atau $\mathrm{R}$ dan $\mathrm{Dt}$ semakin besar kemungkinan risiko gangguan kesehatan. Sedangkan variabel berat badan $(\mathrm{Wb})$ berlawanan arah dengan besar risiko variabel dependen yang berarti bahwa semakin besar nilai berat badan semakin berkurang risiko gangguan kesehatan.

\section{Pembahasan}

Penelitian ini merupakan penelitian kuantitatif dengan menggunakan pendekatan studi cross sectional 
Tabel 1. Hasil Analisis Variabel yang Masuk dalam Model

\begin{tabular}{llccc}
\hline \multirow{2}{*}{ Variabel } & \multicolumn{2}{c}{ Koefisien non-standar } & Koefisien Standar- $\beta$ & $p$-value \\
\cline { 2 - 3 } & \multicolumn{1}{c}{ B } & Std. Error & & \\
\hline Constant & $-0,5960$ & 0,073 & - & 0,000 \\
Konsentrasi Cadmium (C) & 2,756 & 0,133 & 0,932 & 0,000 \\
Laju Asupan (R) & 0,0021 & 0,000 & 0,579 & 0,000 \\
Durasi Pajanan (Dt) & 0,0278 & 0,001 & 0,856 & 0,000 \\
Berat Badan (Wb) & $-0,0095$ & 0,001 & $-0,330$ & 0,000 \\
\hline
\end{tabular}

Tabel 2. Model Hasil Akhir Analisis Regresi Linier Ganda

\begin{tabular}{|c|c|c|c|c|}
\hline \multirow{2}{*}{ Variabel } & \multicolumn{2}{|c|}{ Koefisien non-standar } & \multirow{2}{*}{ Koefisien Standar- $\beta$} & \multirow{2}{*}{$p$-value } \\
\hline & B & Std. Error & & \\
\hline Constant & $-0,212$ & 0,140 & - & 0,132 \\
\hline Konsentrasi Cadmium $(\mathbf{C})$ & $-0,492$ & 0,290 & $-0,166$ & 0,091 \\
\hline Laju Asupan $(\mathbf{R})$ & $-0,00084$ & 0,000 & $-0,231$ & 0,020 \\
\hline Durasi Pajanan (Dt) & $-0,0012$ & 0,003 & $-0,036$ & 0,685 \\
\hline Berat Badan (Wb) & 0,0139 & 0,002 & 0,480 & 0,000 \\
\hline Interaksi $(\mathbf{C} * \mathbf{R})$ & 0,0128 & 0,000 & 0,537 & 0,000 \\
\hline Interaksi (C*Dt) & 0,1250 & 0,005 & 1,229 & 0,000 \\
\hline Interaksi $(\mathbf{C} * \mathbf{W b})$ & $-0,0404$ & 0,005 & $-0,813$ & 0,000 \\
\hline Interaksi ( $\left(\mathbf{R}^{*} \mathbf{D t}\right)$ & 0,000095 & 0,000 & 0,977 & 0,000 \\
\hline Interaksi $(\mathbf{R} * \mathbf{W b})$ & $-0,000025$ & 0,000 & $-0,471$ & 0,000 \\
\hline Interaksi (Dt*Wb) & $-0,00039$ & 0,000 & $-0,816$ & 0,000 \\
\hline
\end{tabular}

yang mengkaji masalah pada saat penelitian dilaksanakan. Variabel dependen (besar risiko) dan variabel independen (konsentrasi cadmium dalam ikan, laju asupan, durasi pajanan dan berat badan) diamati pada waktu yang bersamaan, tanpa memberikan perlakukan kepada responden sehingga rancangan ini mempunyai kelemahan karena tidak dapat menunjukkan hubungan sebab akibat. Faktor risiko sulit diukur secara akurat dan kurang valid untuk meramalkan suatu kecenderungan.

Keterbatasan lain dalam penelitian analisis risiko ini antara lain adalah: (a) Sampel ikan yang diuji hanya mewakili jenis ikan yang sering ditangkap dan dimakan saja. Dengan demikian, tidak semua ikan yang dimakan oleh setiap responden diuji dilaboratorium, selain karena sulit dilakukan juga karena membutuhkan biaya yang besar. (b) Perhitungan asupan pada setiap responden dilakukan berdasarkan konsumsi ikan yang paling sering dimakan, meskipun kadang-kadang mereka mengkonsumsi jenis ikan yang lain. (c) Penelitian ini tidak melakukan pengukuran langsung pada biomarker, seperti pada darah dan urin manusia karena belum ada referensi kejadian penyakit kronis yang disebabkan oleh keracunan logam cadmium di sekitar lokasi penelitian, khususnya Teluk Lampung. Mengingat, penyakit kronis yang disebabkan oleh logam cadmium terjadi dalam kurun waktu yang relatif lama (20-30 tahun).

Analisis risiko merupakan salah satu metode kajian efek lingkungan terhadap kesehatan masyarakat yang sangat cocok untuk memprediksi dampak pencemaran lingkungan terhadap kesehatan masyarakat. Untuk mendukung metode ini, digunakan data hasil kajian epidemiologi sebelumnya. Hal penting antara studi epidemiologi dengan analisis risiko adalah penilaian outcome. Dalam analisis risiko, outcome hanya dinyatakan dengan cara menaksir (memprediksi) risiko yang telah, sedang, dan akan terjadi yang didapat dari sumber-sumber, outcome adalah kejadian penyakit yang berbasis lingkungan. ${ }^{6}$

Hasil penelitian menunjukkan rata-rata konsentrasi cadmium dalam ikan adalah $0,212 \mathrm{mg} / \mathrm{kg}(\mathrm{ppm})$. Konsentrasi tersebut telah melampaui batas rekomendasi yang diperbolehkan yaitu 0,2 ppm dan sekitar 56\% masyarakat di Pulau Pasaran tersebut telah mengkonsumsi ikan yang mengandung cadmium lebih dari 0,2 ppm. Kadar cadmium tertinggi terdapat pada ikan teri asin $(0,407 \mathrm{ppm})$. Padahal sebagian besar $(47,08 \%)$ masyarakat Pulau Pasaran juga mengkonsumsi ikan teri asin. 
Kandungan cadmium pada teri asin ternyata lebih besar daripada teri basah. Kandungan cadmium dalam teri asin yang tinggi ini kemungkinan disebabkan oleh kontaminasi cadmium pada proses pengolahan. Mengingat pengolahan ikan teri basah (segar) dilakukan terlebih dahulu merebusnya dengan air laut yang diambil disekitar pantai Pulau Pasaran dan ditambahkan dengan garam. Dugaan ini diperkuat dari hasil penelitian Wiryawan B, dkk pada tahun 2002 yang menyatakan bahwa air laut di Teluk Lampung telah mengandung cadmium antara 0,024-0,044 ppm (baku mutu air laut kadar $\mathrm{Cd}<0,01 \mathrm{ppm})$. Dugaan kontaminasi dari garam perlu dianalisis terlebih dahulu, mengingat sebagian besar garam yang digunakan oleh para pengolah ikan asin berasal dari Pulau Jawa dan Madura.

Meskipun memperlihatkan hubungan yang lemah, ternyata konsentrasi cadmium dalam ikan berhubungan linier secara bermakna dengan besar risiko. Orang yang mengkonsumsi ikan dengan konsentrasi cadmium lebih dari 0,2 ppm berisiko 7,23 kali lebih besar untuk mengalami gangguan kesehatan daripada orang yang mengkonsumsi ikan dengan kandungan cadmium kurang dari atau sama dengan 0,2 ppm. Logam cadmium di dalam tubuh manusia akan terakumulasi, sehingga semakin besar asupan cadmium ke alam tubuh, semakin besar pula risiko untuk mengalami gangguan kesehatan.

Kandungan cadmium dalam ikan tidak terlepas dari pencemaran lingkungan, baik oleh limbah industri, transportasi maupun limbah rumah tangga. Teluk Lampung merupakan wilayah perairan yang padat dengan kegiatan industri, transportasi (pelayaran internasional), perhotelan dan perumahan yang berpotensi mencemari air laut dan kehidupan biotanya, baik plankton maupun nekton (ikan). Namun sangat disayangkan, Pemerintah Daerah Provinsi Lampung melalui instansi Badan Pengendalian Dampak Lingkungan selama ini tidak melakukan pemantauan logam berat dalam air laut di Teluk Lampung. Selama ini, pemantauan yang dilakukan hanya terbatas pada parameter kimia $(\mathrm{pH}$, suhu, salinitas, daya hantar listrik, oksigen terlarut, padatan tersuspensi, kekeruhan, $\mathrm{BOD}_{5}$ dan COD). ${ }^{7}$

Dalam penelitian ini laju asupan harian terbesar konsumsi ikan didapat pada keluarga nelayan sampai mencapai $400 \mathrm{~g} / \mathrm{hari}$. Laju asupan berhubungan secara signifikan dengan besar risiko, meskipun hubungan tersebut lemah $(r=0,156)$ dan orang yang mengkonsumsi ikan dengan laju asupan lebih besar atau sama dengan 233,6 g/hari berisiko lebih besar 7,118 kali lebih besar untuk mengalami gangguan kesehatan mereka yang mengkonsumsi ikan dengan laju asupan kurang dari 233,6 g/hari. Laju asupan harian cadmium yang berasal dari ikan berkisar antara 22,7 $\mu \mathrm{g}-64,6 \mu \mathrm{g}$. Laju asupan normal yang diperbolehkan dengan sumber pajanan makanan adalah tidak boleh lebih dari $20 \mu \mathrm{g}$.
Rata-rata masyarakat pulau pasaran telah terpajan cadmium melalui ikan selama 21 tahun dan sekitar $35,2 \%$ responden telah terpajan cadmium selama lebih dari 25 tahun, sebagai akibat perilaku masyarakat yang tidak berpindah-pindah. Jika pindah, mereka akan tinggal dilokasi yang serupa (dipulau/pantai), seperti di Muara Angke (Jakarta). Pajanan logam cadmiun yang terus menerus dapat menimbulkan gangguan bahkan kerusakan pada sistem kerja ginjal yang dapat dideteksi dengan mengukur kandungan protein yang terdapat dalam urin (proteinuria). Proteinuria hanya dapat ditemukan pada orang-orang yang telah mengalami pajanan cadmium dalam rentang waktu 20-30 tahun. Informasi ini dapat dijadikan acuan pada penelitian berikutnya dengan melakukan pemeriksaan klinis (uji proteinuria) pada responden yang telah terpajan lebih dari 20 tahun, untuk membuktikan kemungkinan gangguan fungsi ginjal.

Hasil penelitian menunjukkan bahwa durasi pajanan mempunyai hubungan yang kuat $(r=0,725)$ dan sangat signifikan ( $p$-value $=0,000$ ). Responden yang terpajan lebih dari 25 tahun berisiko 7,89 kali lebih besar untuk mengalami gangguan kesehatan daripada responden yang terpajan kurang dari atau sama dengan 25 tahun. Pemajanan cadmium dengan konsentrasi yang rendah dalam jangka waktu yang lama akan menimbulkan kasus keracunan kronis akibat cadmium. Keracunan yang diakibatkan dilingkungan kerja menyebabkan kerusakan ginjal (renal dysfunction) dan pembengkakan paru-paru (emphysema).

Berat badan manusia mencerminkan status gizi seseorang. Gizi yang buruk akan berpengaruh terhadap menurunnya daya tahan tubuh seseorang dan terjadinya gangguan kesehatan. Sebesar 32\% responden dalam penelitian ini memiliki berat badan kurang dari 50 $\mathrm{kg}$. Berat badan berpengaruh terhadap nilai risiko dan secara teoritis, semakin berat badan seseorang semakin kecil risiko mengalami gangguan kesehatan. Pernyataan tersebut terbukti dalam penelitian ini yang secara bivariat menemukan berat badan berhubungan bermakna (nilai $\mathrm{p}=0,032$ ) dengan besar risiko meskipun lemah $(r=0,127)$ dan dengan pola yang negatif. Itu berarti bahwa semakin tinggi berat badan responden semakin kecil besaran risiko, responden dengan berat badan kurang dari 56,7 kg berisiko 3,26 kali lebih besar daripada yang mempunyai berat badan $\geq$ $56,7 \mathrm{~kg}$. Orang dengan berat badan ideal akan mempunyai nutrisi yang cukup sehingga menghalangi kehadiran logam cadmium ke dalam tubuh untuk menggantikan nutrisi (zink, besi, tembaga, selenium, kalsium, piridoksin, asam askorbat, dan protein). Kebanyakan toksisitas cadmium terjadi karena defisiensi unsur-unsur tersebut di atas yang menyebabkan peningkatan absorbsi cadmium. ${ }^{8}$

Meskipun, sekitar 56\% masyarakat Pulau Pasaran te- 
Persamaan 3.

Besar Risiko $=-0,212-0,492 * \mathbf{C}-0,00084 * \mathbf{R}-0,0012 * \mathbf{D t}+0,0139 * \mathbf{W b}+0,0128(\mathbf{C} * \mathbf{R})+0,1250(\mathbf{C} * \mathbf{D t})$ $-0,0404(\mathbf{C} * \mathbf{W b})+0,000095\left(\mathbf{R}^{*} \mathbf{D t}\right)-0,000025(\mathbf{R} * \mathbf{W b})-0,00039\left(\mathbf{D} \mathbf{t}^{*} \mathbf{W b}\right)$

lah mengkonsumsi ikan yang mengandung cadmium untuk mengalami gangguan kesehatan akibat pajanan cadmium secara ingesti (oral) dipengaruhi oleh berbagai faktor antara lain, konsentrasi cadmium dalam ikan (risk agent), laju asupan, durasi pajanan, dan berat badan. Pernyataan ini didukung oleh hasil analisis bivariat (Regresi Linier Sederhana) bahwa semua faktor yang berpengaruh tersebut berhubungan secara bermakna dengan besarnya risiko.

Analisis multivariat (Regresi Linier Ganda) juga memperlihatkan hasil yang sangat signifikan, semua faktor konsentrasi cadmium dalam ikan (risk agent), laju asupan, durasi pajanan, dan berat badan berhubungan secara linier dengan besar risiko gangguan kesehatan akibat cadmium. Analisis regresi linier ganda merupakan model matematis yang dapat digunakan untuk mengetahui bentuk hubungan antara dua atau lebih variabel. Tujuan analisis regresi adalah untuk membuat perkiraan (prediksi) nilai suatu variabel (dependen) melalui variabel lain (independen).${ }^{9}$ Berdasarkan hasil analisis regresi linier ganda didapatkan model prediksi besarnya risiko gangguan kesehatan masyarakat Pulau Pasaran akibat logam cadmium pada persamaan 3 .

Model persamaan regresi di atas tepat digunakan untuk memprediksi besar risiko pada penelitian ini, nilai $p$ value $=0,000$ (sangat signifikan). Konsentrasi cadmium dalam ikan dan durasi pajanan $(\mathrm{C} * \mathrm{Dt})$, berpengaruh paling besar terhadap besar risiko dengan koefisien standard- $\beta=1,229$ dan koefisien korelasi parsial 0,831. Model akhir regresi linier ganda didapatkan nilai koefisien determinasi $\mathrm{R}^{2}=0,985$, artinya persamaan garis regresi linier yang diperoleh ini dapat menjelaskan 98,5\% variasi besarnya risiko masyarakat untuk mengalami gangguan kesehatan akibat logam cadmium. Pada penelitian ini, kemampuan model regresi linier ganda untuk memprediksi besar risiko tergolong baik karena nilai $\mathrm{R}^{2}$ diatas $60 \%$, nilai yang baik untuk penelitian kesehatan adalah jika $\mathrm{R}^{2}>60 \%$. Hal ini disebabkan data yang digunakan dalam semua variabel merupakan data numerik. Semakin besar nilai $\mathrm{R}^{2}$ semakin baik (akurat) kemampuan variabel independen memprediksi variabel dependen (besar risiko). Besarnya nilai $\mathrm{R}^{2}$ berkisar antara 0 sampai 1 atau antara $0 \%$ sampai $100 \% .{ }^{9}$

\section{Kesimpulan}

Masyarakat Pulau Pasaran Kota Karang-Bandar Lampung telah berisiko mengalami gangguan kesehatan akibat logam cadmium. Dengan rata-rata laju asupan per hari konsumsi ikan masyarakat adalah 233,56 gr/hari; konsentrasi rata-rata cadmium dalam ikan 0,212 ppm; rata-rata durasi pajanan cadmium dalam ikan adalah 20,967 tahun; berat badan responden rata-rata adalah $56,65 \mathrm{~kg}$; rata-rata besar risiko masyarakat pulau Pasaran Kota Karang-Bandar Lampung adalah 0,574. Hasil analisis bivariat didapatkan faktor risiko yang berhubungan signifikan dengan besar risiko adalah konsentrasi cadmium dalam ikan (C), laju asupan (R), durasi pajanan (Dt) dan berat badan $(\mathrm{Wb})$. Sedangkan hasil analisis multivariat didapatkan faktor dominan yang menentukan besar risiko adalah konsentrasi cadmium dalam ikan dan durasi pajanan.

\section{Saran}

Perlu penelitian lanjutan untuk menganalisis biomarker terhadap sampel urin atau darah pada kelompok individu yang telah terpajan lebih dari 25 tahun. Perlu dikembangkan dan dilakukan surveilens dan pemetaan terhadap kelompok masyarakat yang berisiko mendapat gangguan kesehatan akibat cadmium. Perlu dilakukan pengawasan mutu ikan olahan secara periodik terhadap bahan baku pengolahan ikan asin dan ikan asin hasil olahan. Perlu penilaian terhadap kualitas air laut mengingat pertumbuhan industri di Teluk Lampung berkembang pesat.

\section{Daftar Pustaka}

1. WHO. Environmental health criteria 135: cadmium environmental aspects. Geneva: WHO; 1992.

2. Satarug S and Moore MR. Adverse health effects of chronic exposure to low-level cadmium in foodstuffs and cigarette smoke. Environmental Health Perspective. 2004; 112(10): 1099-1103.

3. Wiryawan, dkk. ATLAS sumber daya wilayah pesisir Lampung. Edisi Cetakan ke-2. 2002.

4. Kanawasari dan Purnomo. Pemeriksaan logam berat cadmium (Cd) pada beberapa ikan laut dari tempat pelelangan ikan lempasing Lampung Selatan (Karya Tulis Ilmiah). 2004.

5. Yassi, Kjellstrom, de Kok, dan Guidotti. Basic environmental health. Oxford University Press; 2001.

6. Rahman. Analisis kualitan lingkungan. Modul KML 22420. Edisi 5. Depok: Laboratorium KL FKM UI; 2004.

7. Bapedalda Propinsi Lampung. Laporan tahunan kegiatan subbid pembinaan laboratorium tahun 2004. Lampung: Bapedalda; 2004.

8. Darmono. Lingkungan hidup dan pencemaran (hubungannya dengan toksikologi senyawa logam). Jakarta: UI-Press; 2001.

9. Hastono. Analisis data (modul). Depok: FKM UI; 2001. 